\title{
Application of Clay \\ Mineral-Iridium(III) Complexes Hybrid Langmuir-Blodgett Films for Photosensing
}

\author{
Hisako Sato, Kenji Tamura and Akihiko Yamagishi
}

Additional information is available at the end of the chapter

http://dx.doi.org/10.5772/47793

\section{Introduction}

There has been an extensive interest in developing photo-responsive devices based on luminescent transition metal complexes (Sato \& Yamagishi, 2007). As a promising applicant for emitting composites, cyclometalated iridium(III) complexes are attracting a wide attention due to their highly emitting properties in a visible region (Lo et al., 2011, Ulbricht et al., 2009). The lifetime of the excited triplet states is very long (ca. $1 \mu \mathrm{s}$ ) and the quantum yield attains a value as high as $10 \sim 100 \%$. These iridium(III) complexes are used for photoresponsive molecular devices such as photo-diodes and oxygen sensors (Lowry \& Benhard, 2006, Sajoto et al., 2009 ). The attempts are based on the fact that energy transfer takes place efficiently from the triplet excited state of an iridium(III) complex to semiconductors or an oxygen molecule in the triplet ground state.

Clay is an environmentally-friendly ubiquitous material. They are characterized by layered structures with cation-exchange properties (Ogawa \& Kuroda, 1995). Cationic molecules are intercalated in the narrow galleries between aluminosilicate layers. The materials are used as a host for various types of photochemical reactions. We recently studied the interactions of cationic iridium(III) complexes with a colloidally dispersed clay (Sato et al., 2009, 2011a). The adsorption of iridium(III) complexes by a clay was found to result in the drastic enhancement of emission intensity in an aqueous solution. The attempts demonstrate that emission behavior often provide a key to monitoring the delicate change of adsorption structures.

Recently the application of clay minerals for photochemical reactions was further extended to thin-film systems. For such purposes, luminescent Langmuir-Blodgett (LB) films were prepared by depositing the monolayers of amphiphilic iridium(III) complexes onto a glass substrate (Sato et al., 2010). The emission properties of a single layered film were studied under vacuum or 
under the atmosphere of various gases. As far as our literature survey is concerned, it was the first report on the Langmuir-Blodgett films consisting of iridium(III) complexes with no additives. This pioneering work, however, revealed several problems concerning the low stability and poor reproducibility in sensing functions due to their fragile properties.

In order to overcome the above disadvantages, we attempted to construct a hybrid film of an amphiphilic iridium(III) complex with a clay (Sato et al., 2011b). In these years, the inclusion of layered materials such as layered niobates, titania and clays has been attempted to enhance the mechanical strength of a molecular film and stabilizing its sensor function (Acharya et al. 2009). When clay minerals were used, it was expected that the diversity of elemental compositions of clay sheets might enable us to tune the sensitivity and selectivity of sensing towards a wide range of target molecules. Motivated by these backgrounds, a LB film was constructed by hybridizing an amphiphilic cationic iridium(III) complex with various clays such as synthetic saponite, synthetic hectorite, and natural montmorillonite. As a result, a single layered hybrid LB film was shown to exhibit emission intense enough to study the interaction of the film with gaseous molecules (Sato et al., 2011b). This work would be a benchmark to explore a gas sensor based on cyclometalated iridium(III) complexes.

\section{Interaction of clays with luminescent iridium(III) complexes}

\subsection{Metal ion sensing by luminescence}

Cationic cyclometalated iridium(III) complexes were used as an emitting adsorbate by a clay. We synthesized an iridium(III) complex, $\left[\operatorname{Ir}(\text { ppy })_{2} \mathrm{dmbpy}_{\mathrm{PF}} \mathrm{P}_{6}(\mathrm{ppyH}=2-\right.$ phenylpyridine and dmbpy $=4,4$-dimethylbipyridine: Chart 1 ) (denoted by [Ir(III)L1] complex), according to the reported method (Lowry \& Benhard, 2006). Synthetic saponite (Kunimine Ind. Co.; $\left(\mathrm{Si}_{7.20} \mathrm{Al}_{0.80}\right)\left(\mathrm{Al}_{0.03} \mathrm{Mg}_{5.97}\right) \mathrm{O}_{20}(\mathrm{OH})_{4} \mathrm{Na} 0.77$ (CEC: $75 \mathrm{meq} / 100 \mathrm{~g}$ ) or sodium montmorillonite (Kunipia-P, Kunimine Ind. Co.; (Si7.70 $\left.\left.\mathrm{Al}_{0.30}\right)\left(\mathrm{Al}_{3.12} \mathrm{Mg}_{0.68} \mathrm{Fe}_{0.19}\right) \mathrm{O}_{20}(\mathrm{OH})_{4}\right)$ (Na0.49Mg0.14) (CEC: $115 \mathrm{meq} / 100 \mathrm{~g}$ ) was used as a host material. Adsorption was carried out by mixing a solution of the $\left[\operatorname{Ir}(\mathrm{III}) \mathrm{L}_{1}\right]$ complex with a clay suspension within 10 milliseconds by means of a stopped-flow apparatus. This procedure guaranteed the uniform adsorption of the metal complexes over clay particles particularly at low loading.
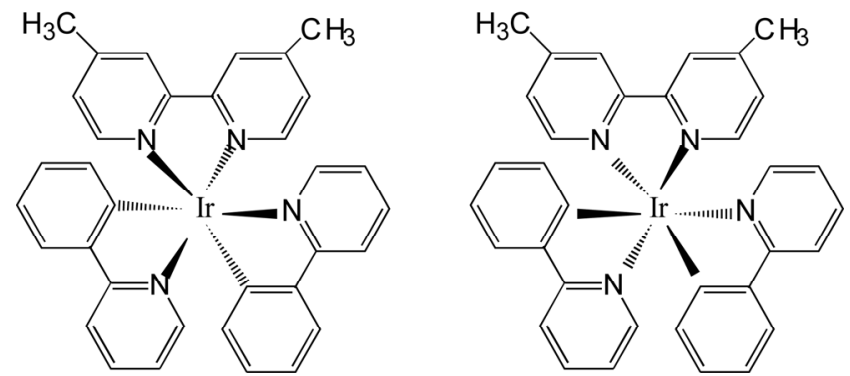

$\Delta$-[Ir(ppy) $2(\mathrm{dmbpy})]^{+}(\mathrm{left})$ and $\Lambda$-[Ir(ppy) $\left.)_{2}(\mathrm{dmbpy})\right]^{+}$(right) $\left(\right.$ppyH $=2$-phenylpyridine and dmbpy $=4,4^{\prime}$-dimethyl2,2'-bipyridine).

Chart 1. Chiral structures of $[\operatorname{Ir}(\mathrm{ppy}) 2 \mathrm{dmbpy}]^{+}$ 
In case of synthetic saponite, the luminescence spectra were measured under air on an aqueous dispersion containing [Ir(III)L1] complex and various amounts of a clay. Notably quantum yield $(\Phi)$ increased from 0.04 to ca.1.0 with the increase of an added clay even in an aqueous dispersion as shown in Fig. 1. The main cause for the increase of $\Phi$ might lie in the elimination of water molecules in the vicinity of the [Ir(III)L1] complexes located on a clay surface. The structural fixation of a flexible ligand (dmbpy) in the [ $\left.\operatorname{Ir}(\mathrm{III}) \mathrm{L}_{1}\right]$ complex could be another factor. The introduction of air had little effects on $\Phi$. The fact was in marked contrast with the homogeneous media, in which oxygen molecules quench the excited complexes efficiently. Thus a clay provided such a site as protected from quenching by oxygen molecules. The emission intensity continued to increase even after the equivalent amount of a clay and attained the maximum value around [clay $] /\left[\operatorname{Ir}(\mathrm{III}) \mathrm{L}_{1}\right]=10$. This might reflect that the adsorbed complexes were in an isolated state, being free from the self-quenching among them.

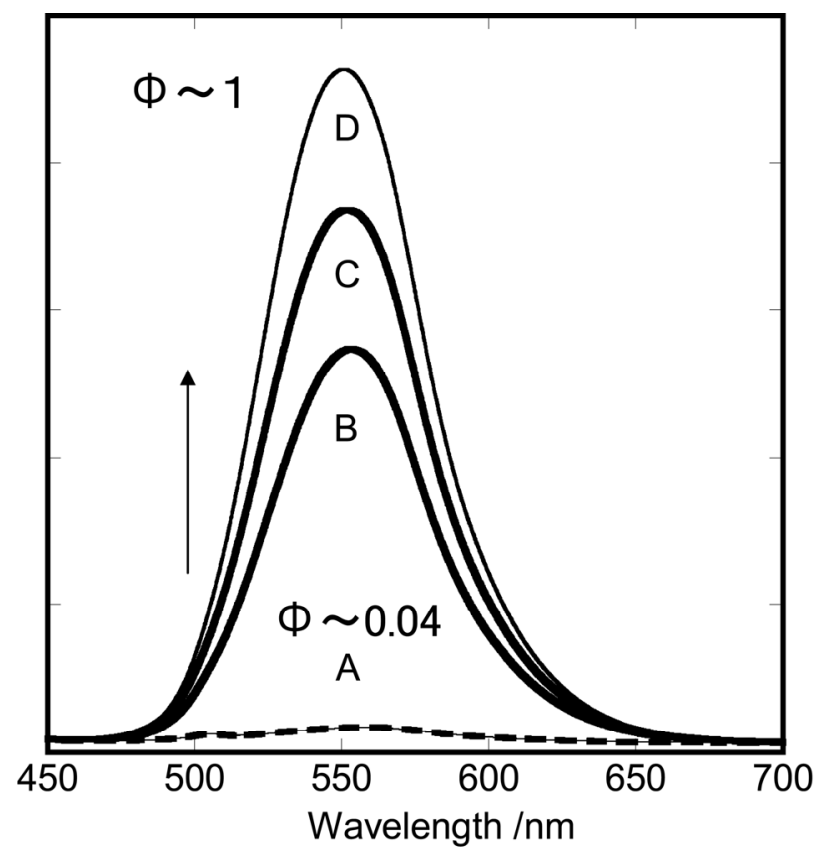

Figure 1. The effect of synthetic saponite on the luminescence spectra of [Ir(bpy $\left.)_{2} d m b p y\right]+$ under degassed condition. The excitation wavelength was $430 \mathrm{~nm}$. The concentration of [Ir(III)L1] complex was $1 \times 10^{-5} \mathrm{M}$ and clay (A) $0.0 \mathrm{M}$, (B) $1.0 \times 10^{-5} \mathrm{M}$, (C) $4.0 \times 10^{-5} \mathrm{M}$ and (D) $1.0 \times 10^{-4} \mathrm{M}$. The lowest dotted curve was an emission spectrum for the absence of a clay. A solvent was 3:1(v/v) $\mathrm{H}_{2} \mathrm{O} / \mathrm{CH}_{3} \mathrm{OH}$.

The effect of a clay on the transient behavior of excited [Ir(III)L1] complexes was studied by the lifetime measurements under various conditions. Under air, the decay profile was composed of at least two components. This suggested that there were more than two kinds of adsorption states. For example, a part of the complexes were in the interlayer space and the other on the external surface of a clay. If it was the case, the latter state was more easily quenched by oxygen molecules in correspondence to the shorter component of life time. Under argon 
atmosphere, the decay profile for a clay dispersion changed to a single exponential curve whose lifetime was nearly equal to the longer component under air. This was reasonable since the $\operatorname{Ir}(\mathrm{III})$ complexes on an external surface were no more quenched by oxygen molecules.

In case of sodium montmorillonite, the emission quantum yield $(\Phi)$ of the complex decreased by adsorption on a clay particle. The behavior was ascribed to the quenching by Fe(III) ions located in a layer and partly by water molecules as shown in Fig. 2. Interestingly $\Phi$ recovered by adding alkali or alkaline-earth metal ions to a clay suspension. The results were rationalized in terms of the model that the quenching by Fe(III) ions. The effect of metal ions on the recovery of luminescence indicated that bound metal ions diminished the quenching ability of water molecules. It was suggested that the adsorption of metal ions hydrated water molecules on the clay surface. Such hydration might deprive water molecules of quenching ability towards the $\left[\operatorname{Ir}(\mathrm{III}) \mathrm{L}_{1}\right]$ complexes. If that is the case, the effect is thought to be critically dependent on the charge of the metal ion, because the hydration is stronger for metal ions of higher valence. The fact that alkaline earth metal ions were more effective than alkali metal ions was in accord with this view. It should be emphasized that the influence of metal ions as observed here appeared at concentrations as low as $10^{-5} \mathrm{M}$. No work has ever revealed such hydration effects by metal ions at such a low concentration. Highly emitting properties of the present $\left[\mathrm{Ir}(\mathrm{III}) \mathrm{L}_{1}\right]$ complex enabled us to detect the effect under those extreme conditions. From a practical point of view, the present finding may open the possibility of developing the sensing of metal ions by use of the emission from a clay-metal complex adduct.

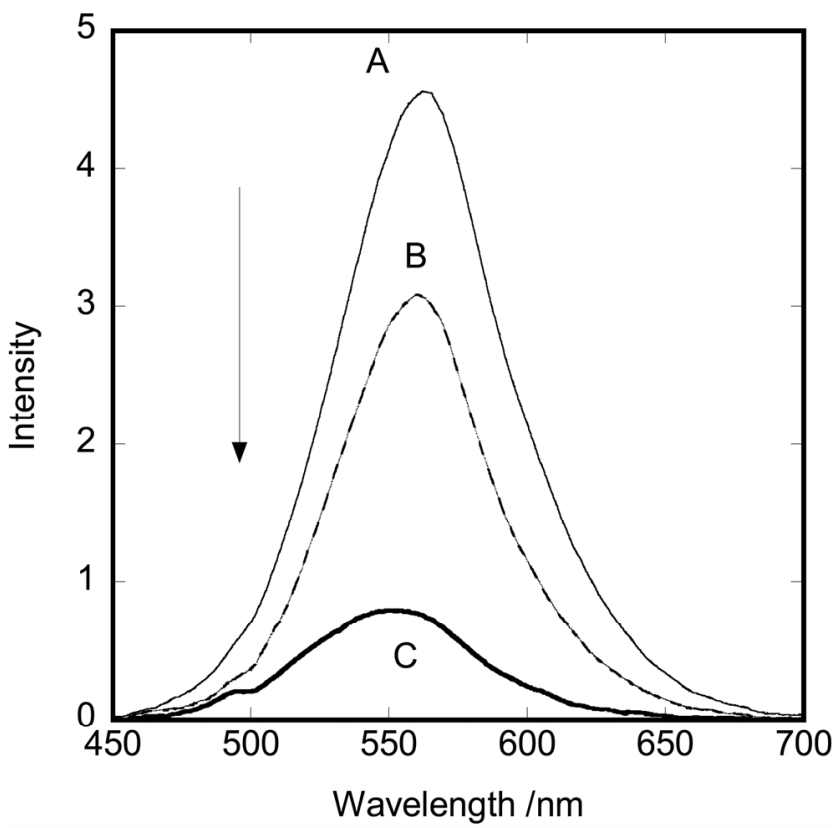

Figure 2. Luminescence spectra of an aqueous dispersion containing $[\operatorname{Ir}(\mathrm{ppy}) 2 \mathrm{dmbpy}]^{+}\left(6.5 \times 10^{-6} \mathrm{M}\right)$ and various amounts of clay ((A) $\left.0.0 \mathrm{M},(\mathrm{B}) 1.5 \times 10^{-5} \mathrm{M}(\mathrm{C}) 1.8 \times 10^{-4} \mathrm{M}\right)$. The maximum loading of [Ir(III)L1] complex was $5.4 \%$ with respect to the CEC of clay. 


\subsection{Enantioselective sensing by luminescence}

Clay minerals have been also applied as a host in the photochemical reactions involving optically active molecules (Fujita et al., 2006). It should be noted that enantioselective luminescence quenching is a dynamical recognition phenomenon (Inoue, 1992, Tsuchiya et al., 2009). The discrimination of chirality is accomplished within the short lifetime of an excited molecule. Clay may assist the emitter to orient preferably for the stereoselective attack by a quencher. If the emitting properties of the [ $\left.\operatorname{Ir}(\mathrm{III}) \mathrm{L}_{1}\right]$ complexes are connected with their chiral structures, it may open a possibility for luminescent chiral sensing. Under these backgrounds, a clay mineral is used as a host to fix the orientation of an iridium(III) complex towards a quencher (Sato et al., 2011a).

The highly emitting properties of the iridium complex bound by a clay prompted us to investigate the possibility of stereoselective energy transfer. The optical resolution of a cationic iridium(III) complex, $\left[\operatorname{Ir}(\mathrm{ppy})_{2} \mathrm{dmbpy}\right]^{+}$(Chart 1), was attempted by several ways such as anionic resolving reagent and chiral adsorbents (Chen et al., 2007). The only successful method was to use an ion-exchange adduct of a clay and chiral $\left[\operatorname{Ru}(\mathrm{phen})_{3}\right]^{2+}$ (phen $=1,10$-phenanthroline) as a resolving agent. As a chiral quencher, a tris $(\beta$ diketonato)ruthenium(III), [Ru(acac)3] (Chart 2), was chosen.

The emission intensity at $650 \mathrm{~nm}$ was compared between two systems, clay $/ \Delta$-[Ir(III)L1] $/ \Delta$ $\left[\mathrm{Ru}(\mathrm{acac})_{3}\right]$ (pseudo-enantiomeric combination) and clay $/ \Delta-\left[\operatorname{Ir}(\mathrm{III}) \mathrm{L}_{1}\right] / \Lambda-\left[\mathrm{Ru}(\mathrm{acac})_{3}\right]$ (pseudoracemic combination), in 3:1 (v/v) water-methanol. In both cases, the intensity of emission decreased on adding $\left[\mathrm{Ru}(\mathrm{acac})_{3}\right]$, indicating that $\mathrm{Ru}(\mathrm{III})$ complex acted as an efficient quencher in these systems. The quenching effect was analyzed in terms of the Stern-Volmer plots (Eq. (1)). It was apparent that luminescence quenching was more efficient for the clay/ $\Delta-\left[\operatorname{Ir}(\mathrm{III}) \mathrm{L}_{1}\right]$ $/ \Delta-\left[\mathrm{Ru}(\mathrm{acac})_{3}\right]$ system than for the clay $/ \Delta-\left[\operatorname{Ir}(\mathrm{III}) \mathrm{L}_{1}\right] / \Lambda$ - $\left[\mathrm{Ru}(\mathrm{acac})_{3}\right]$ over the whole concentration range. The plots showed the tendency of leveling off at the higher concentration of the quenchers. The curves were fitted by the two-site model as given by Eq . (2):

$$
\frac{I_{0}}{I}=1+\frac{K_{q}}{K_{F}}\left[P_{O_{2}}\right]
$$

Here, $k_{q}$ and $k_{F}$ are the bimolecular rate constant of quenching and the unimolecular rate constant of spontaneous luminescence, respectively.

$$
\begin{aligned}
& \frac{I_{0}}{I}=\left[\frac{f_{1}}{1+K_{s v 1} P_{o}}+\frac{f_{2}}{1+K_{s v 2} P_{o}}\right]^{-1} \\
& f_{1}+f_{2}=1 \\
& K_{s v_{0}}=f_{1} \times K_{s v 1}+f_{2} \times K_{s v 2}
\end{aligned}
$$

in which $I_{0}, I, f_{1}, f_{2}, P_{0}, K_{s v 1}$ and $K_{s v 2}$ denote the emission intensities in the absence of and in the presence of a quencher, the fractions of processes 1 and 2, the concentration of a quencher and the Stern-Volmer constants for the processes 1 and 2, respectively. $K_{s v 0}$ is the overall Stern-Volmer constant. 

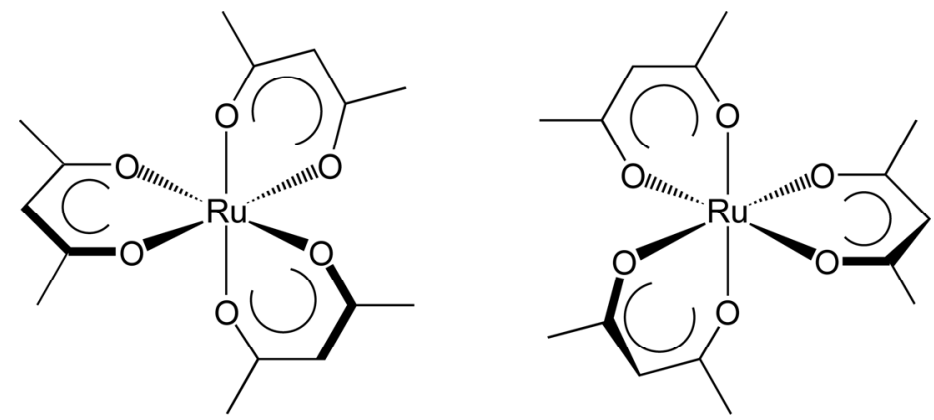

Chart 2. Chiral structures of $\left[\mathrm{Ru}(\mathrm{acac})_{3}\right]$ as a quencher: $\Delta-\left[\mathrm{Ru}(\mathrm{acac})_{3}\right]$ (left) and $\Lambda-\left[\mathrm{Ru}(\mathrm{acac})_{3}\right]$ (right)

In order to confirm the existence of stereoselectivity, we performed the same experiments for the opposite emitter/quencher combinations or the clay/ $\Lambda$-[Ir(III) $\left.\mathrm{L}_{1}\right] / \Lambda$-[Ru(acac) 3$]$ (pseudo-enantiomeric combination) and the clay/ $\Lambda-\left[\operatorname{Ir}(\mathrm{III}) \mathrm{L}_{1}\right] / \Delta-\left[\mathrm{Ru}(\mathrm{acac})_{3}\right]$ (pseudo-racemic combination). From the $K_{s v 0}$ obtained from Eq. 2, the overall selectivity factor, which is defined to be the ratio of $K_{s v 0}(\Delta-\Delta$ or $\Lambda-\Lambda) / K_{s v 0}(\Delta-\Lambda)$, was obtained to be 1.84 in favor of the pseudo-enantiomeric combination. The quenching reaction was not a simple collisional process, but it might involve the process of molecular association on a clay surface. It was added that no stereoselectivity was detected in methanol for the same emitter/quencher pairs. Thus the fixation of the iridium(III) complex on a clay surface was concluded to be a crucial step for chiral recognition as shown in Scheme 1.

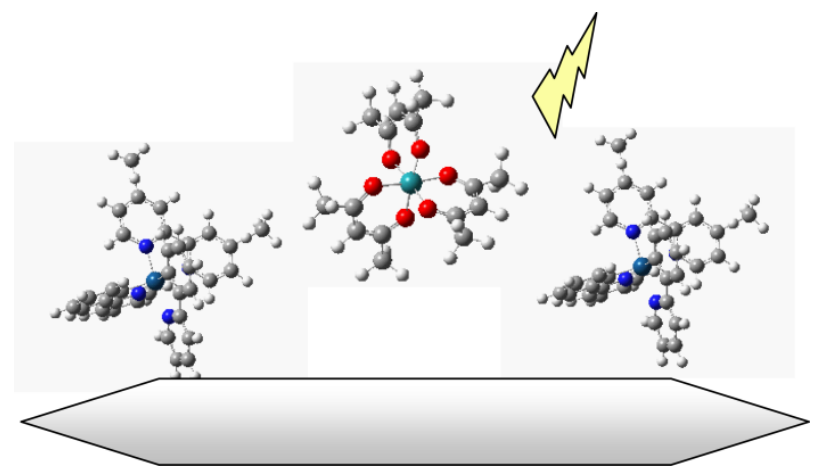

Scheme 1. A model of chiral sensing by [Ir(III)L1] complexes adsorbed on a clay surface

\section{Preparation of thin films of clays by the Langmuir-Blodgett (LB) method}

The photochemical reactions involving clay minerals were further extended to thin film systems. In such attempts, the preparation of thin films with uniform properties is essentially important to achieve well-defined reaction systems. Yamagishi et al. first reported the nanometer-thick films of an ion-exchange adduct of a clay (synthetic saponite) 
and an alkylammonium cation (trimethylstearylammonium) as prepared by the LangmuirBlodgett method. (Inukai et al., 1994). For preparing such a film, the ion-exchanged adduct of a clay-alkylammonium is dispersed in chloroform and spread over the surface of pure water. According to the method, a layer-by-layer film was prepared in such a way as donor and acceptor molecules were intercalated in an alternative order. It was revealed that a single clay layer acted as an efficient barrier in the transfer of photon energy. For example, the photoinduced electron-transfer was studied from an amphiphilic polypyridyl-Ru(II) complex (electron donor) to an amphiphilic acetylacetonato-Ru(III) complex (electron acceptor). Recently the method was called as "Clay LB Method"(Tamura et al. , 1999, Ras et al., 2009). We have been attempting to improve the "Clay LB Method" in order to develop nano-structured photodevices based on clay minerals (Sato et al., 2005).
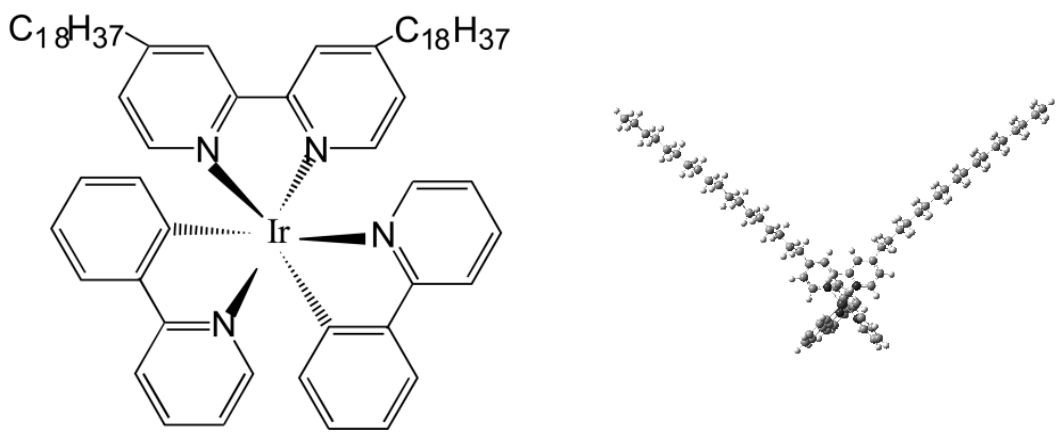

Chart 3. The structure of $\left[\operatorname{Ir}(\text { ppy })_{2}(\mathrm{dc} 18 \mathrm{bpy})\right]^{+}$

An amphiphilic cyclometalated iridium(III) complex, $\left[\operatorname{Ir}(\text { ppy })_{2}(\mathrm{dc} 18 \mathrm{bpy})\right] \mathrm{ClO}_{4}$ (ppy = 2phenylpyridine; dc18bpy = 4,4'-dioctadecyl-2,2'-bipyridine) (denoted by [Ir(III)L2] (Chart 3)), was prepared by refluxing $\left[\operatorname{Ir}(\mathrm{ppy})_{2} \mathrm{Cl}\right]_{2}$ with an equal amount of dc18bpy in glycerol at $170{ }^{\circ} \mathrm{C}$ for 8 hours. The compound was purified chromatographically by being eluted on an HPLC column (MG (Shiseido Inc. Ltd.)) with chloroform. The Langmuir-Blodgett (LB) method has been applied for preparing a thin clay film as shown in Scheme 2. The details of preparation is described below. A LB trough with an area of $10.0 \mathrm{~cm} \times 13.0 \mathrm{~cm}$ is maintained at $20^{\circ} \mathrm{C}$ by circulating water. The clays used can be synthetic saponite or sodium montmorillonite or synthetic hectorite $\left.\left(\mathrm{Si}_{8.00}\right)\left(\mathrm{Mg}_{3.50} \mathrm{Li}_{0.30}\right) \mathrm{O}_{20}(\mathrm{OH})_{4}\right)$ (Na0.70). A chloroform solution of an amphiphilic cationic iridium(III) complex, $\left(\left[\operatorname{Ir}(\text { ppy })_{2}(\mathrm{dc} 18 \mathrm{bpy})\right] \mathrm{ClO}_{4}\left(3.2 \times 10^{-5} \mathrm{molL}^{-1}\right)\right.$, is spread onto an aqueous suspension of a clay at various concentrations. As a reference, the same solution is spread over pure water. A floating monolayer is formed on the surface of a subphase. The surface pressure versus molecular area $(\pi-A)$ curves is obtained by compressing the monolayer. Figure 3 shows the example for $\pi$-A curves with $0 \mathrm{mgL}^{-1}, 10 \mathrm{mgL}^{-1}$ and $20 \mathrm{mgL}^{-1}$ of synthetic saponite. In all cases, surface pressure levels off from zero in the region of the molecular area below $0.5-1.5 \mathrm{~nm}^{2}$ per molecule. A critical molecular area (Sc) is obtained by extrapolating the linear portion of each $\pi$-A curve to zero surface pressure. Both Sc changes significantly, when a subphase of pure water is replaced with a clay suspension. Moreover the slope of 
$\pi$-A curve becomes steeper by this replacement, indicating that the floating films are more rigid on hybridization with clay particles. These facts support the occurrence of hybridization of a molecular film of [ $\left.\operatorname{Ir}(\mathrm{III}) \mathrm{L}_{2}\right]$ complex with clay particles at an air-water interface. In these cases, $10 \mathrm{mgL}^{-1}$ of clay is concluded to be the best condition for the rigid films. Since the sectional area of the head groups of the present complex is estimated to be ca. $1 \mathrm{~nm}^{2}$ on a molecular model, a floating film is concluded to be composed of the monolayer of the metal complex.

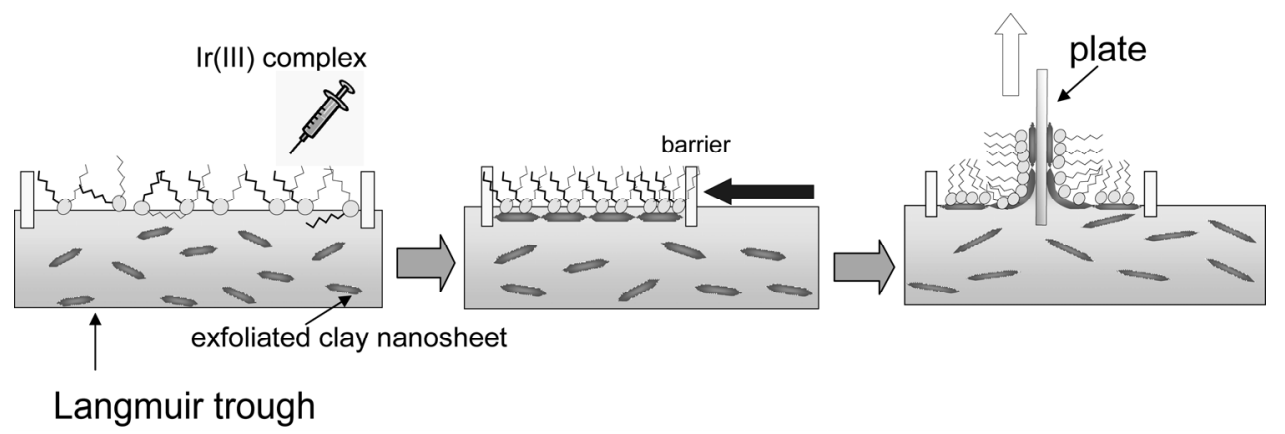

Scheme 2. Clay LB method (vertical deposition)

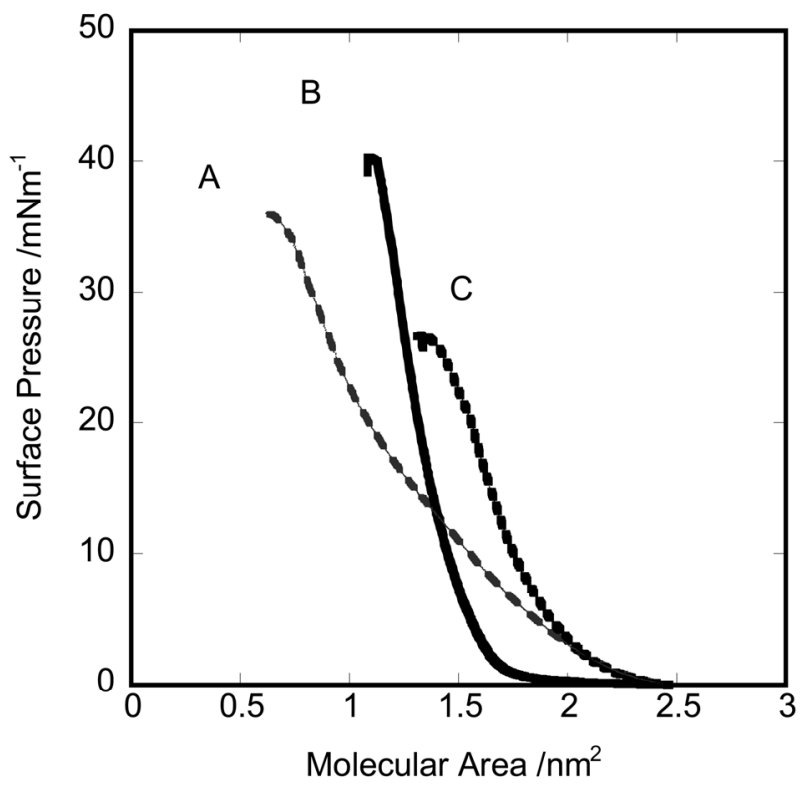

Figure 3. The surface pressure versus molecular area $(\pi-\mathrm{A})$ curves when a chloroform solution of $\left[\operatorname{Ir}(\right.$ ppy) $2(\mathrm{dc} 18 \mathrm{bpy})] \mathrm{ClO}_{4}$ was spread over a subphase of $(\mathrm{A})$ pure water, or $(\mathrm{B})$ synthetic saponite $(10 \mathrm{mg}$ $\mathrm{L}^{-1}$ ) or (C) synthetic saponite $\left(20 \mathrm{mgL}^{-1}\right)$. 


\section{Structures and properties of clay LB films}

This section describes how the structure of a LB clay film is studied. After $30 \mathrm{~min}$, the surface was compressed at a rate of $10 \mathrm{~cm}^{2} \mathrm{~min}^{-1}$ until the surface pressure reached $10 \mathrm{mNm}$ ${ }^{1}$. A floating film was transferred at $10 \mathrm{mNm}^{-1}$ onto a hydrophilic glass plate or silicon by the vertical method at a dipping rate of $10 \mathrm{~mm} \mathrm{~min}^{-1}$. The transfer ratio was estimated to be $0.9 \pm$ 0.1 for all cases. The AFM images of the deposited film showed the presence of particles with the characteristic shape depending on the kind of clay. They definitely demonstrated the inclusion of clay particles in the deposited films. In case of synthetic saponite, for example, the film was composed of spherical domains with the diameter of ca. $50 \mathrm{~nm}$, which indicated the presence of saponite particles. [ $\operatorname{Ir}(\mathrm{III}) \mathrm{L}_{2}$ ] complexes were thought to be attached uniformly by the particles. In case of synthetic hectorite, the flat regions with the height of ca. $2 \mathrm{~nm}$ were observed, indicating the inclusion of hectorite particles. Small domains were observed on such a flat region, which corresponded to the aggregated states of $\left[\operatorname{Ir}(\mathrm{III}) \mathrm{L}_{2}\right]$ complexes. In case of montmorillonite, the films were covered with flat particles in various shapes. The thickness of the flat particle was estimated to be ca. $2 \mathrm{~nm}$. Subtracting the thickness of one clay layer $(1 \mathrm{~nm})$ from this value, the height of an iridium(III) complex was estimated to be $1 \mathrm{~nm}$. This was less than one-half of the molecular length of the iridium complex along the long alkyl chains. Thus these complexes were thought to be adsorbed with their alkyl chains declined from a clay surface.

\section{Application of clay-iridium(III) complex LB films for photo-sensing}

\subsection{Emission properties of the deposited hybrid LB films}

The emission behavior was investigated on a hybrid film of an $\left[\operatorname{Ir}(\mathrm{III}) \mathrm{L}_{2}\right]$ complex and a clay as prepared by the LB method. For measurement of emission spectra from a LB film, a glass substrate was placed in a quartz cell at 45 degrees with respect to the incident light (Scheme 3(a)). A gas was introduced into the cell after it was evacuated below $0.1 \mathrm{~m}$ torr. The emission spectra was measured under vacuum at room temperature when these substrates were irradiated by a light at $430 \mathrm{~nm}$ (Scheme 3(b)).
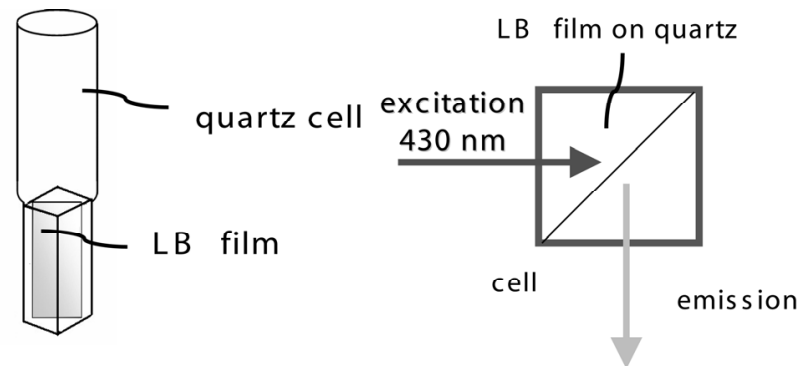

Scheme 3. (a) A quartz cell containing a substrate modified with a LB film; (b) Experimental set-up of measuring an emission spectrum from a film in a quartz cell 
The emission peak was slightly dependent on the kind of hybridized clay: $550 \mathrm{~nm}$ for synthetic saponite, synthetic hectorite and montmorillonite, and $535 \mathrm{~nm}$ for without clay, respectively. The emission intensity was nearly doubled for hybridization with saponite in comparison to that of without clay. Since these films contained nearly the same amount of [Ir(III) $\left.\mathrm{L}_{2}\right]$ complexes as in the film without clay, the increase was thought to be caused by the interaction with a clay surface. Figure 4 shows the emission spectra of [ $\left.\operatorname{Ir}(\mathrm{III}) \mathrm{L}_{2}\right] /$ synthetic saponite and $\left[\operatorname{Ir}(\mathrm{III}) \mathrm{L}_{2}\right] /$ pure water. The complexes formed a mono-molecular layer on a clay surface, while they were coagulated to form a multi-molecular layer in the pure LB film. Thus the self-quenching by neighboring molecules would be reduced on a clay surface in comparison to the pure LB film. Among the hybrid films, no enhancement of emission intensity was observed for montmorillonite, probably because Fe(III) ions in a clay layer had an effect of quenching excited iridium(III) complexes.
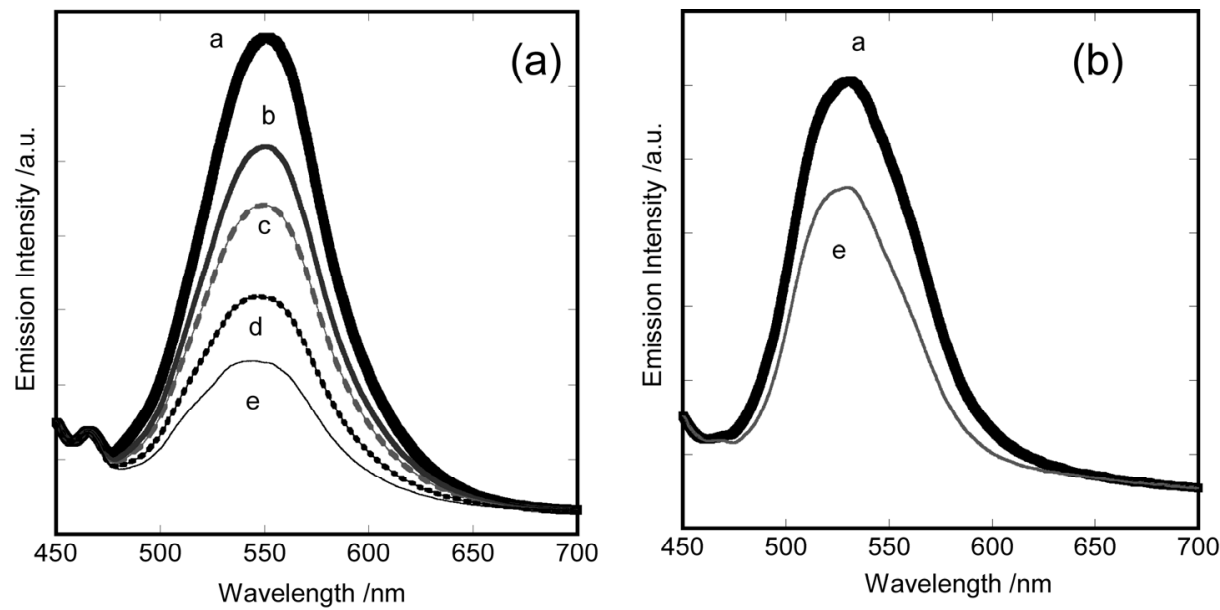

Figure 4. Emission spectra from (a) [Ir(III)L2]/synthetic saponite and (b) $\left[\operatorname{Ir}(\mathrm{III}) \mathrm{L}_{2}\right] /$ no clay: oxygen pressure was (a) vacuum, (b) 3.7, (c) 9.0 , (d) 31.4 and (e) $101.3 \mathrm{kPa}$, respectively. The films were prepared for an aqueous dispersion containing $10 \mathrm{mg} \mathrm{L}^{-1}$ of synthetic saponite. The excitation wavelength was $430 \mathrm{~nm}$.

\subsection{Quenching effects by oxygen and other gaseous molecules}

In order to pursue the possibility of applying a clay hybrid films for oxygen sensing, the effect of oxygen gas was studied on the emission behavior. The emission of $\left[\operatorname{Ir}(\mathrm{III}) \mathrm{L}_{2}\right] /$ montmorillonite in air was shown in Fig.5. An oxygen gas was introduced into a quartz cell containing a glass substrate modified with a single-layered hybrid LB film. The emission decreased rapidly until it attained the stationary value within a few seconds. It recovered to the initial value by evacuating the oxygen gas. The results implied that the electronic energy of the [ $\left.\operatorname{Ir}(\mathrm{III}) \mathrm{L}_{2}\right]$ complex in the excited triplet state transferred efficiently to an oxygen molecule in the triplet ground state, leading to the formation of a singlet oxygen molecule. As shown in the Figures 4 and 6, the quenching phenomena were 
observed at the various oxygen pressures. The decrease of emission intensity was evaluated as a function of oxygen pressure. $\mathrm{I}_{0} / \mathrm{I}$ is plotted as a function of oxygen pressure ([PO2]). Here I and Io denote the luminescence intensity at $550 \mathrm{~nm}$ with and without a quencher, respectively. The plots were analyzed according to the equation (Stern-Volmer plots Eq. (1)) The experimental plot did not obey a linear relation but curved downwards at the higher pressure region. The effect was interpreted in terms of the presence of different types of oxygen quenching sites. Assuming that there were two sites for quenching, the curves are fitted by Eq. (2). Comparing the weighted quenching constant among four films, hybrid saponite LB film showed the highest sensitivity towards $\mathrm{O}_{2}$.

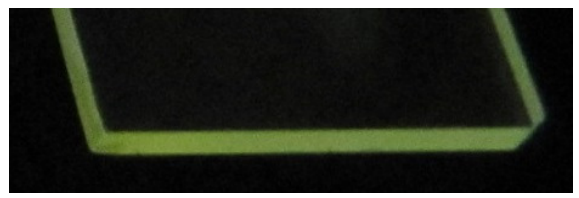

Figure 5. Emission from an $\left[\operatorname{Ir}(\mathrm{III}) \mathrm{L}_{2}\right] /$ montmorillonite LB film deposited on a quartz substrate in air.

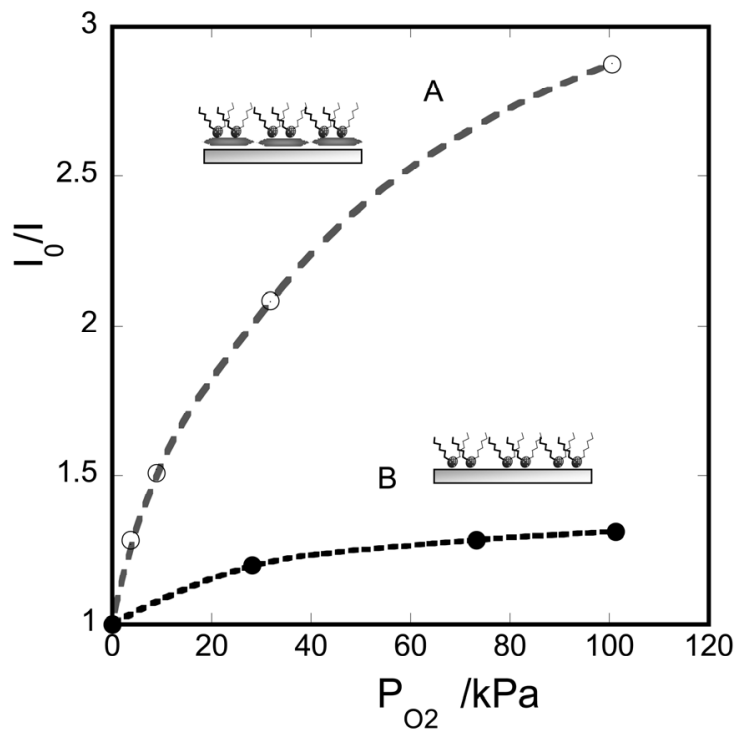

Figure 6. Dependence of the change of emission intensity on the vapor pressure of oxygen gas for (A) $\left[\operatorname{Ir}(\mathrm{III}) \mathrm{L}_{2}\right] /$ synthetic saponite and $(\mathrm{B})\left[\operatorname{Ir}(\mathrm{III}) \mathrm{L}_{2}\right] /$ no clay. The excitation and emission wavelengths were $430 \mathrm{~nm}$ and $550 \mathrm{~nm}$, respectively. The luminescence intensity was recorded at $535 \mathrm{~nm}$ for $[\operatorname{Ir}(\mathrm{III}) \mathrm{L} 2] / \mathrm{no}$ clay. Curves were fit by two-site model proposed by Eq. (2).

For other gases such as water, ethanol, acetone and chloroform, similar experiments were performed on the hybrid LB films of various clays. All these gases acted as a quencher in deactivating the excited iridium(III) complexes. Since these molecules were in the singlet states in contrast to an oxygen molecule, they were assumed to relax the electronic energy of an excited iridium(III) complex non-radiatively through their vibration energy levels. The time 
course of the emission intensity was dependent on the kinds of clays remarkably (Fig.7). For the case of $\left[\operatorname{Ir}(\mathrm{III}) \mathrm{L}_{2}\right] /$ montmorillonite, for example, the signal was reversible for introducing and evaporating gases. The results were consistent with the uniform adsorption of iridium(III) complexes on the clay particle as observed in the AFM image. For the case of $\left[\operatorname{Ir}(\mathrm{III}) \mathrm{L}_{2}\right] /$ synthetic hectorite, however, methanol and acetonitrile increased emission intensity instead of acting as a quencher. The results suggested that the self-quenching among [Ir(III)L2] complexes decreased by the inclusion of the gas molecules. The disordering of the alkoxy chains might result in the decrease of quenching among the neighboring [ $\left.\mathrm{Ir}(\mathrm{III}) \mathrm{L}_{2}\right]$ complexes in the film. It was noted that a small molecule with functional group such as $-\mathrm{OH},>\mathrm{C}=\mathrm{O}, \mathrm{CN}$ and $-\mathrm{Cl}$ quenched the excited [Ir(III) $\mathrm{L}_{2}$ ] complexes efficiently, while molecules with nofunctional group such as cyclohexane affected little the emission from the hybrid films. Thus the energy relaxation into vibration energy levels occurred exclusively through the specific interaction of the [Ir(III) $\left.\mathrm{L}_{2}\right]$ complexes with these functional groups.

oxygen water methanol ethanol acetone acetonitrile chloroform cyclohexane

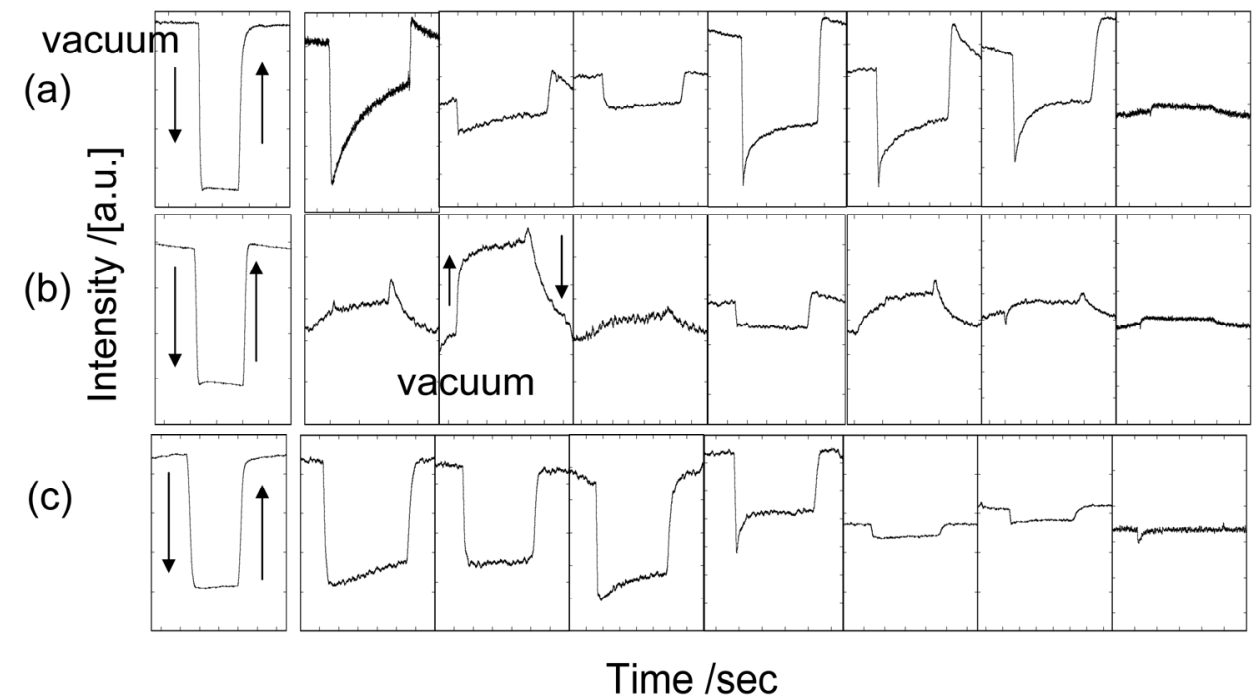

Figure 7. Effects of gases on the time course of the emission intensity for the singly deposited hybrid LB films: (a) [Ir(III)L2]/synthetic saponite, (b) [Ir(III)L2]/synthetic hectorite and (c) [Ir(III)L2]/montmorillonite. The luminescence intensity was measured at $550 \mathrm{~nm}$, respectively. The following gases were used: oxygen, water, methanol, ethanol, acetone, acetonitrile, chloroform and cyclohexane. $101.3 \mathrm{kPa}$ of oxygen was introduced. In other gases, about one-third of their saturation vapor pressure was introduced. The films were prepared for an aqueous dispersion containing $10 \mathrm{mg} \mathrm{L}^{-1}$ of clay. The excitation wavelength was $430 \mathrm{~nm}$.

For comparison, the effect of an oxygen gas on the luminescence was studied for the cast film of saponite ion-exchanged with the [ $\left.\operatorname{Ir}(\mathrm{III}) \mathrm{L}_{2}\right]$ complex. The quenching effect was much less efficient than that for the LB films. The results were reasonable, considering the situations that only a small portion of $\left[\operatorname{Ir}(\mathrm{III}) \mathrm{L}_{2}\right]$ complexes were located on the external 
surface of the film. In this sense, the sensitivity for sensing gas molecules was remarkably enhanced by constructing a LB film with nanometer thickness.

\section{Conclusion}

The hybrid Langmuir-Blodgett (LB) films of an amphiphilic iridium(III) complex, $[\operatorname{Ir}(\mathrm{ppy}) 2(\mathrm{dc} 18 \mathrm{bpy})]^{+}$, and clays (synthetic saponite, synthetic hectorite, and sodium montmorillonite) were prepared. A glass substrate was modified with a single layered LB film and placed into a quartz cell. Luminescence was monitored under the atmosphere of various gases. An oxygen gas, for example, quenched the emission from excited iridium(III) complexes linearly in the pressure range of $0-30 \mathrm{kPa}$, while the quenching effect was saturated above $30 \mathrm{kPa}$, The results indicated the occurrence of adsorption saturation of oxygen molecules into the film. Other gases with functional groups also quenched the luminescence efficiently. These results demonstrated the potentiality of the present hybrid LB films as a gas sensing device.

\section{Author details}

Hisako Sato

Department of Chemistry, Graduate School of Science and Engineering,

Ehime University, Matsuyama, Japan

Kenji Tamura

National Institute of Materials Science, Tsukuba, Japan

Akihiko Yamagishi

School of Medicine, Toho University, Ota-ku, Tokyo, Japan

\section{Acknowledgement}

This work has been financially supported by MEXT KAKENHI Grant-Aid-for Scientific Research (B) Number 23350069 of Japan. The part of work was financially supported by Nippon Sheet Glass Foundation of Materials and Science and Engineering of Japan.

\section{References}

Acharya, S., Hill, J. P., \& Ariga, K. (2009). Soft Langmuir-Boldgett Technique for Hard Nannomaterials. Adv. Mater. , Vol. 21, pp.2959-2981.

Chen, X., Okamoto, Y., Yano, T., \& Otsuki, J. (2007). Direct Enantiomeric Separations of Tris (2-phenylpyridine) Iridium (III) Complexes on Polysaccharide Derivative-based Chiral Stationary Phases. J. Sep. Sci., Vol. 30, pp. 713-716.

Fujita, S., Sato, H., Kakegawa, N., \& Yamagishi, A. (2006). Enantioselective Photooxidation of a Sulfide by a Chiral Ruthenium (II) Complex Immobilized on a Montmorillonite Clay Surface: The Role of Weak Interactions in Asymmetric Induction. J. Phys. Chem. B, 110, pp. 2533-2540. 
Inoue, Y. (1992). Asymmetric Photochemical Reactions in Solution. Chem. Rev., Vol. 92, pp. 741-770.

Inukai, K. , Hotta, Y., Taniguchi, M., Tomura, S., \& Yamagishi, A. (1994). Formation of a Clay Monolayer at an Air-Water Interface. J. Chem. SOC. Chem. Commun., pp.959-960.

Lo, K. K.-W., Li, S.P.-Y., \& Zhnag, K. Y. (2011). Development of Luminescent Iridium(III) Polypyridine Complexes as Chemical and Biological Probes. New J. Chem., Vol. 35, pp.265-287.

Lowry, M. S., \& Bernhard, S. (2006). Synthetically Tailored Excited States: Phosphorescent, Cyclometalated Iridium(III) Complexes and Their Applications. Chem. Eur. J. , Vol. 12, pp.7970-7977.

Ogawa, M., \& Kuroda, K. (1995). Photofunctions of Intercalation Compunds. Chem. Rev., Vol. 95, pp. 399-438.

Ras, R. H. A. , Umemura, Y. , Johnston, C. T. , Yamagishi, A. , \& Schoonheydt, R. A. (2007).Ultrathin Hybrid Films of Clay Minerals. Phys. Chem. Chem. Phys., Vol. 9, pp. 918932.

Sajoto, T., Djurovich, P. I., Tamayo, A. B., Oxgaard, J., Goddard III., W. A. \& Thompson, M. E. (2009). Temperature Dependence of Blue Phosphorescent Cyclometalated Ir(III) Complexes. J. Am. Chem. Soc., Vol. 131, pp.9813-9822.

Sato, H., Hiroe, Y., Tamura, K., \& Yamagishi, A. (2005). Orientation Tuning of a Polypyridyl $\mathrm{Ru}(\mathrm{II})$ Complex Immobilized on a Clay Surface toward Chiral Discrimination. J. Phys. Chem. B, Vol. 109, pp.18935-18941.

Sato, H., \& Yamagishi, A. (2007). Application of the $\Delta \Lambda$ Isomerism of Octahedral Metal Complexes as a Chiral Source in Photochemistry. J. Photochem.Photobiol. C; Photochem. Rev., Vol. 8, pp.67-84.

Sato, H., Tamura,K., Taniguchi, M., \& Yamagishi, A. (2009). Metal Ion Sensing by Luminescence from an Ion -exchange Adduct of Clay and Cationic Cyclometalated Iridium (III) Complex. Chem Lett., Vol. 38, pp.14-15.

Sato, H., Tamura, K., Taniguchi , M., \& Yamagishi, A. (2010). Highly Luminescent Langmuir-Blodgett Films of Amphiphilic Ir(III) Complexes for Application in Gas Sensing. New J. Chem., Vol. 34, pp.617-622.

Sato, H., Tamura, K., Aoki, R., Kato, M., \& Yamagishi, A. (2011a). Enantioselective Sensing by Luminescence from Cyclometalated Iridium (III) Complexes Adsorbed on a Colloidal Saponite Clay. Chem. Lett., Vol. 40, pp.63-65.

Sato, H., Tamura, K., Ohara, K., Nagaoka, S. , \& Yamagishi, A. (2011b). Hybridization of Clay Minerals with the Floating Film of a Cationic Ir(III) Complex at an Air-water Interface. New J. Chem., Vol. 35, pp.394-399.

Tamura, K., Setsuda, H., Taniguchi, M., Yamagishi, A. (1999). A Clay-Metal Complex Ultrathin Film as Prepared by the Langmuir-Blodgett Technique. Chem. Lett. , pp.121-122.

Tsuchiya, K., Ito, E., Yagai, S., Kitamura, A., \& Karatsu, T. (2009). Chirality in the Photochemical mer->fac Geometrical Isomerization of Tris(1-Phenyloytrazolato, N, $\mathrm{C}^{2}$ ) Iridium(III). Eur. J. Inorg. Chem., pp. 2104-2109.

Ulbricht, C., Beyer, B., Friebe, C., Winter, A., \& Schubert, U. S. (2009). Recent Developments in the Application of Phosphorescent Iridium (III) Complex Systems. Adv. Mater., Vol. 21, pp.4418-4441. 